\title{
A NEW EXOCRINE GLAND IN THE SLAVE RAIDING ANT GENUS POLYERGUS
}

\author{
BY BERT HÖLlDOBLER* \\ Department of Organismic and Evolutionary Biology, \\ MCZ-Laboratories, Harvard University, \\ Cambridge, Massachusetts
}

\section{INTRODUCTION}

In his classical study of the workers and males of Myrmica rubra, Janet $(1898,1901)$ discovered a pair of clusters of a few glandular cells under the 6th abdominal tergite. Each cell is drained by a duct that penetrates the intersegmental membrane between the 6th and 7 th abdominal tergites. Recent investigations have demonstrated that this gland is very common in ants, but it varies considerably in size and structure (Hölldobler and Engel 1978). Since the gland is anatomically closely associated with the last exposed tergite in female ants (7th abdominal tergite $=$ pygidium) Kugler (1978) suggested that it be called the pygidial gland. Recently Jessen and Maschwitz (1983) proposed the alternative name, Janet's gland, in honor of its discoverer Charles Janet.

The pygidial gland has been found in workers of representative species belonging to all subfamilies except the Formicinae (for literature review see Hölldobler and Engel 1978; Hölldobler and EngelSiegel 1982; Hölldobler 1982).

I report here the first discovery of a pygidial gland in Polyergus, a genus of the subfamily Formicinae. But the anatomy has unusual features that point to a possibly indepedent origin in evolution.

\section{Material AND Methods}

Three species of Polyergus were investigated. The European species Polyergus rufescens was collected near Würzburg (W-Germany), the two North American species $P$. breviceps and $P$. lucidus were found near Portal (Arizona) and near Rocky Point in Suffolk County (New York), respectively. Virgin queens and males were

*Manuscript received by the editor March 24, 1984. 
available only in the case of $P$. lucidus. For comparison two common slave species of $P$. rufescens, Formica rufibarbis and $F$. fusca (from the Würzburg area), as well as two species of the slave raiding Formica sanguinea group (collected in Massachusetts), were also studied.

For histological investigations life specimens were fixed in alcoholic Bouin or Carnoy (Romeis 1948), embedded in methylmethacrylate, and sectioned 6-8 $\mu$ thick with a D-profile steel knife on a Jung Tetrander I microtome (Rathmayer 1962). The staining was Azan (Heidenhain). The SEM pictures were taken with an AMR 1000 A scanning electron microscope.

\section{RESULTS}

Workers and queens of the three Polyergus species investigated possess a large, tergal complex gland. One part of it is located between the 6th and 7th abdominal tergites; the other part belongs to the 7th tergite (Fig. 1). Because of its anatomical location I propose tentatively to call this organ pygidial gland, although it differs in several respects from the pygidial glands found in other ant subfamilies.

The pygidial gland of Polyergus consists of a reservoir, formed by an invagination of the intersegmental membrane between 6 th and 7 th abdominal tergites. Glandular cells $(\sim 80$ cells in $P$. rufescens workers) are drained into this reservoir through ducts penetrating the intersegmental membrane. Ducts of a second group of glandular cells open into a series of cuticular cups located along the anterior margin of the 7 th abdominal tergite (Fig. 1,2). This striking cuticular structure is usually not visible, because it is covered by the posterior portion of the 6th abdominal tergite. It is, however, easily exposed by slightly pulling the two terminal abdominal tergites apart. Although only a few specimens of each species were investigated in detail, species-specific differences in the pygidial cup structure are so conspicuous that this organ might be considered a valid taxonomic character.

The cup structure is most strikingly developed in workers of $P$. rufescens (Fig. 2). In this case several cups are often merged to form one large cup containing 2-5 glandular cell openings. I counted a total of approximately 250 duct openings on the pygidium of $P$. rufescens workers. In workers of $P$. breviceps the cup structure is 

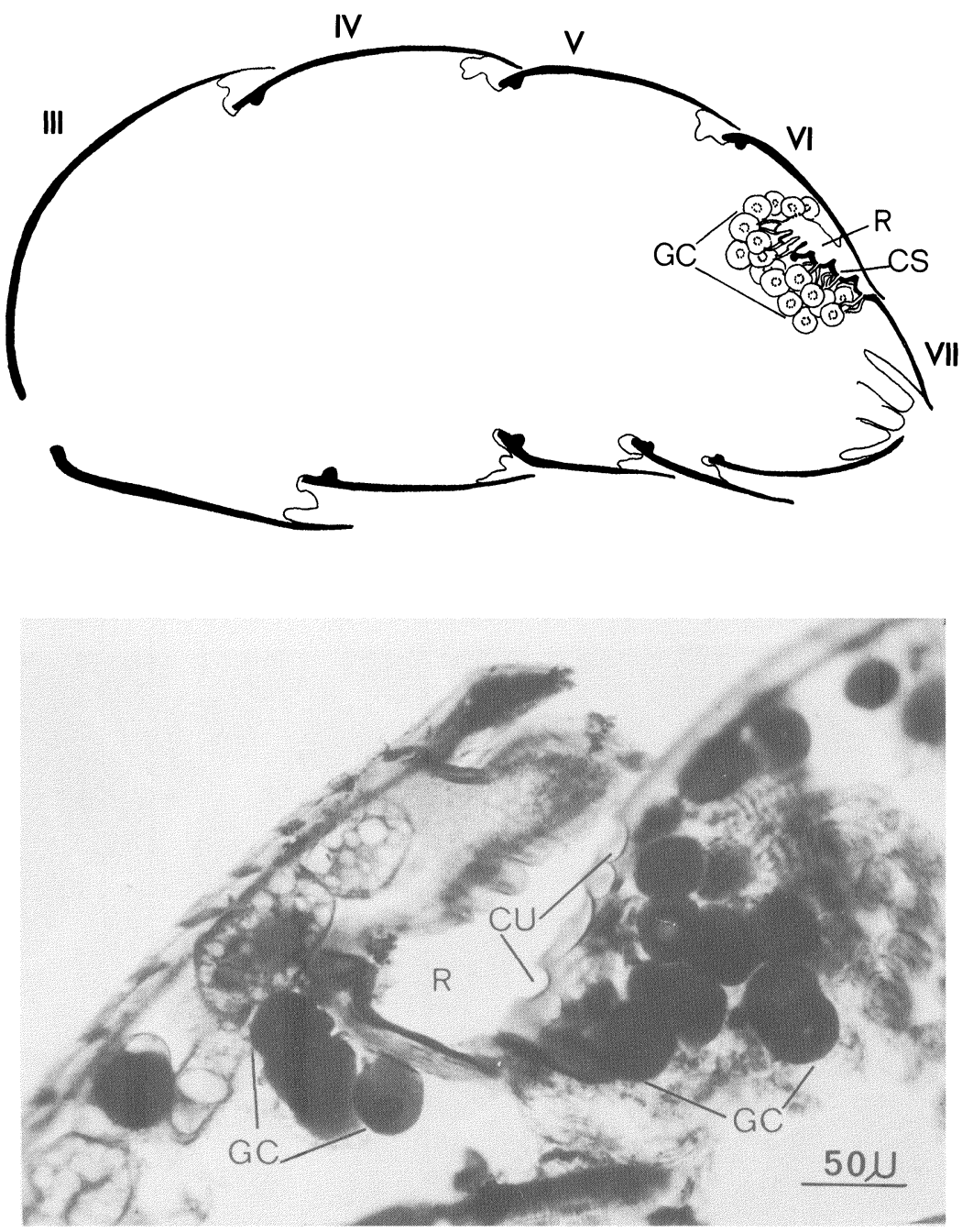

Fig. 1. Above: Schematical illustration of the Polyergus pygidial gland between 6th and 7th abdominal tergites. Below: Longitudinal section through the pygidial gland of a $P$. rufescens worker. CS: cup structure; CU: cup; GC: glandular cells; R: intersegmental reservoir. 

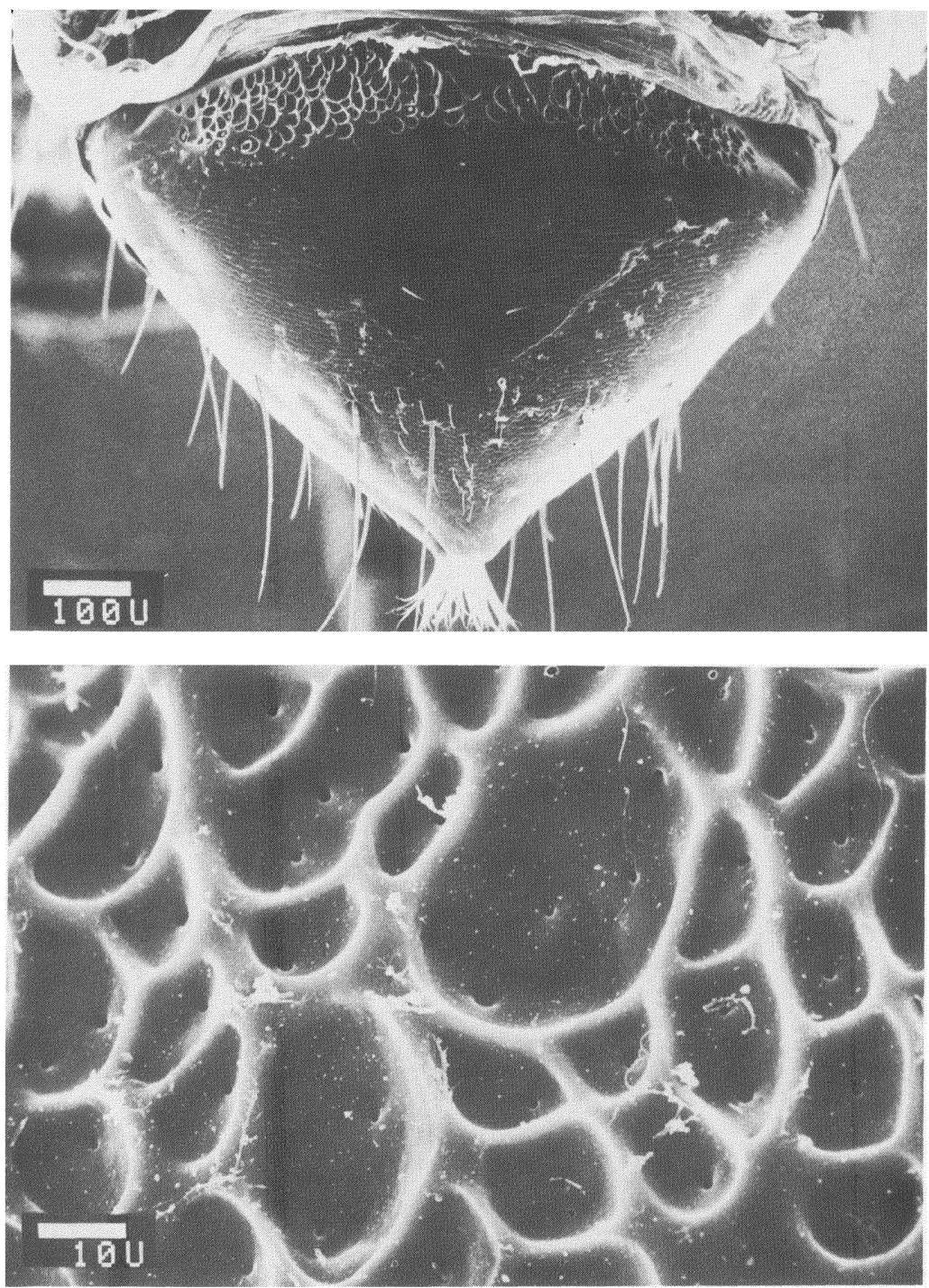

Fig. 2. SEM-photographs of the pygidial cup structure of a P. rufescens worker. Above: overview of the pygidium ( $=7$ th abdominal tergite). Below: close-up of the cup structure. Note the duct openings inside the cups. 
smaller (with a total of $\sim 150$ duct openings), but in this species as well several small cups frequently form one large cup (Fig. 3). In $P$. lucidus workers the pygidial cup structure is still smaller, with approximately 100 duct openings. In this case the cup structure consists primarily of single cups (Fig. 4). It is interesting to note, however, that in $P$. lucidus queens the pygidial cup structure is considerably larger ( $\sim 200$ duct openings), and many of the cups are merged (Fig. 5).

External morphological studies of $P$. lucidus males indicate that they lack the organ.

Formica rufibarbis and $F$. fusca, two common slave species of $P$. rufescens, as well as two representatives of the slave raiding Formica sanguinea group were found not to possess a pygidial gland (Fig. 6).

\section{Discussion}

Of a total of 17 formicine species investigated (the current study and Hölldobler and Engel 1978) belonging to 6 genera (Acantholepis, Camponotus, Formica, Myrmecocystus, Oecophylla, Polyergus) only those in Polyergus possess the pygidial gland. This structure is a complex gland with one group of glandular cells opening into an intersegmental reservoir, and another group of cells being drained into cuticular cups in the 7 th abdominal tergite. From these features and from its general anatomy I conclude that the pygidial gland of Polyergus is not homologous with the pygidial gland of other ant subfamilies, but has evolved independently, possibly in connection with the highly specialized slave raiding behavior of Polyergus.

Polyergus slave raids are organized by scout ants that deposit chemical trails (Talbot 1967). The precise origin of the trail pheromones has not yet been established. In most formicine species secretions from the rectal bladder serve as trail pheromones (for review see Hölldobler 1978). These function in many cases primarily as orientation cues and are often supplemented by excitement (or arousal) signals, which can be chemical or mechanical in nature. Recent observations suggest that recruitment to slave raids in Polyergus might be based on a similar mechanism.

Topoff et al. (1984) found that individual scout ants lead the raiding party of nestmates to the slave ants' nest. He observed that the ants, although following a chemical trail, tend to "swarm" 

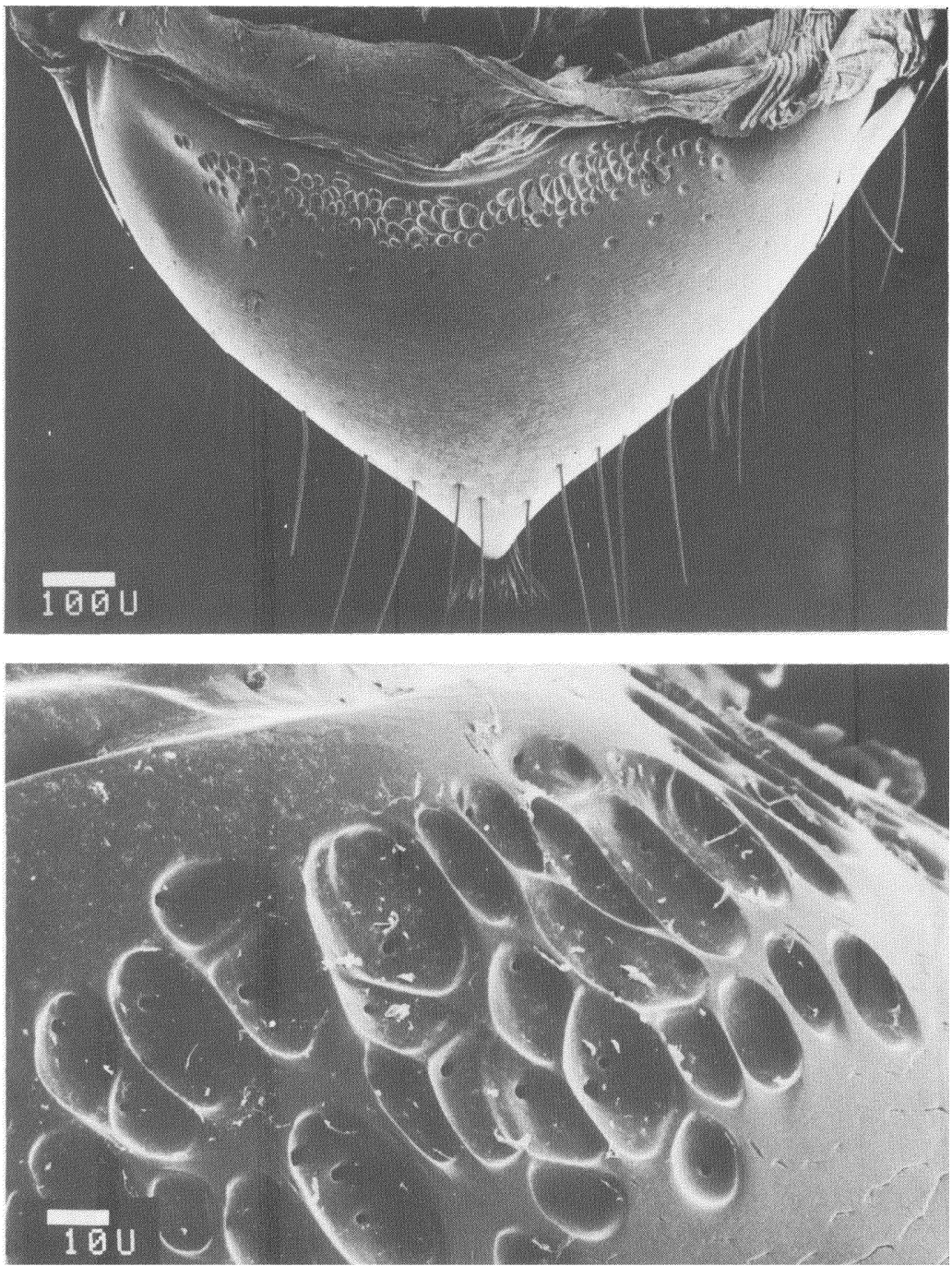

Fig. 3. SEM-photograph of the pygidial cup structure of a P. breviceps worker. Above: overview of the pygidium. Below: close-up of the cup structure. 

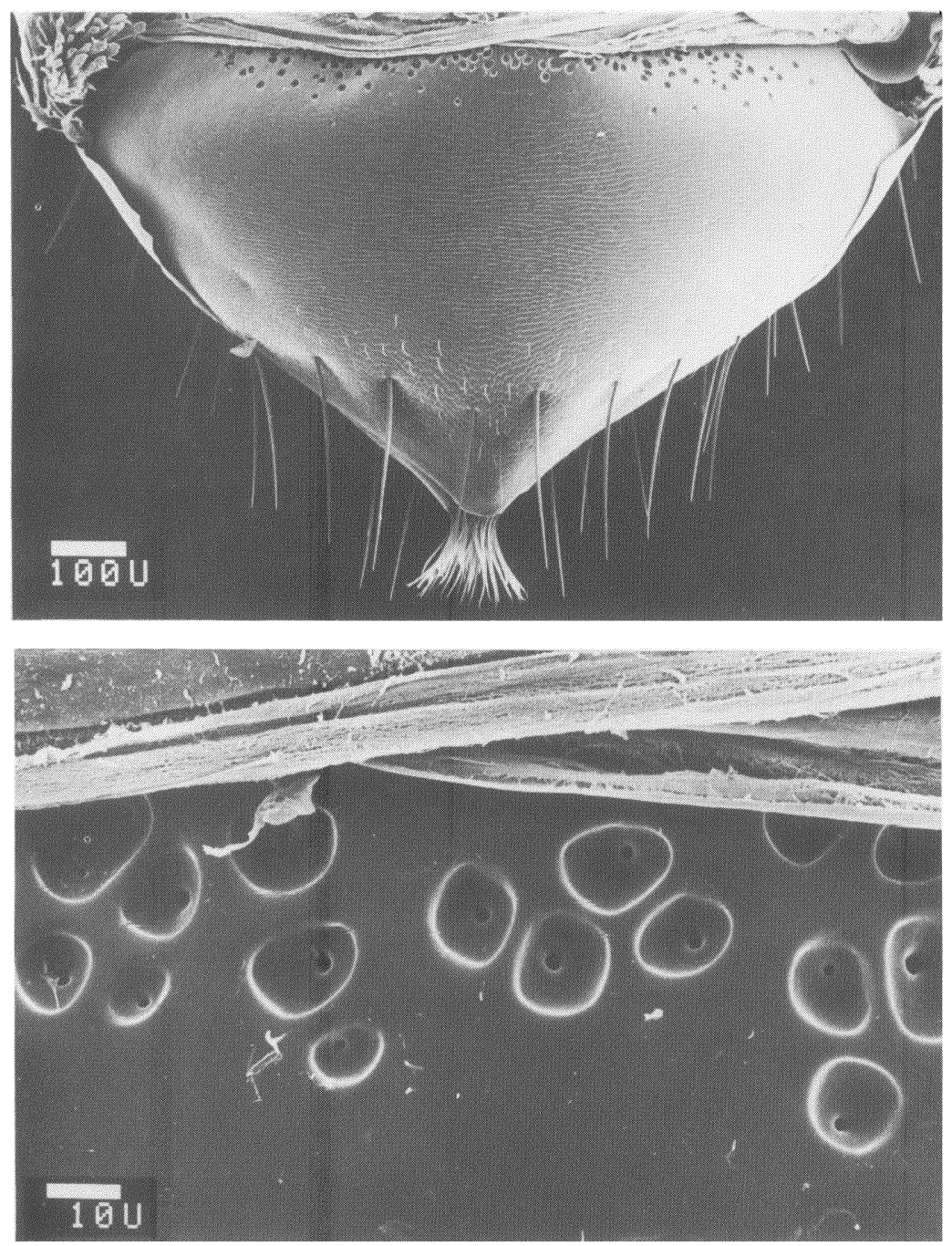

Fig. 4. SEM-photograph of the pygidial cup structure of a $P$. lucidus worker. Above: overview of the pygidium. Below: close-up of cup structure. 

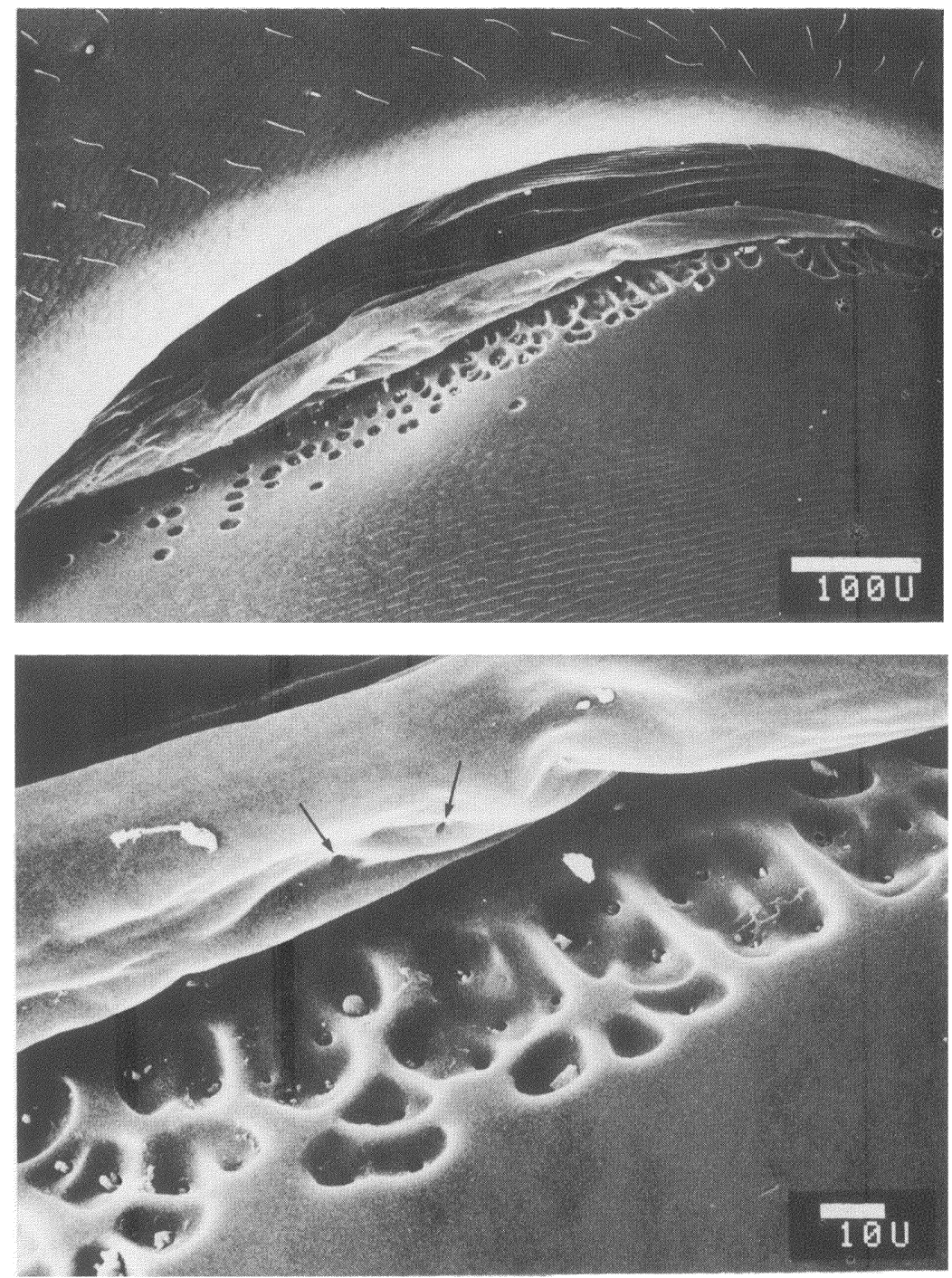

Fig. 5. SEM-photograph of the pygidial cup structure of a $P$. lucidus queen. Above: overview of the cup structure at the anterior margin of the 7 th abdominal tergite. Below: close-up of the cup structure. Arrows point ot the intersegmental duct openings. 


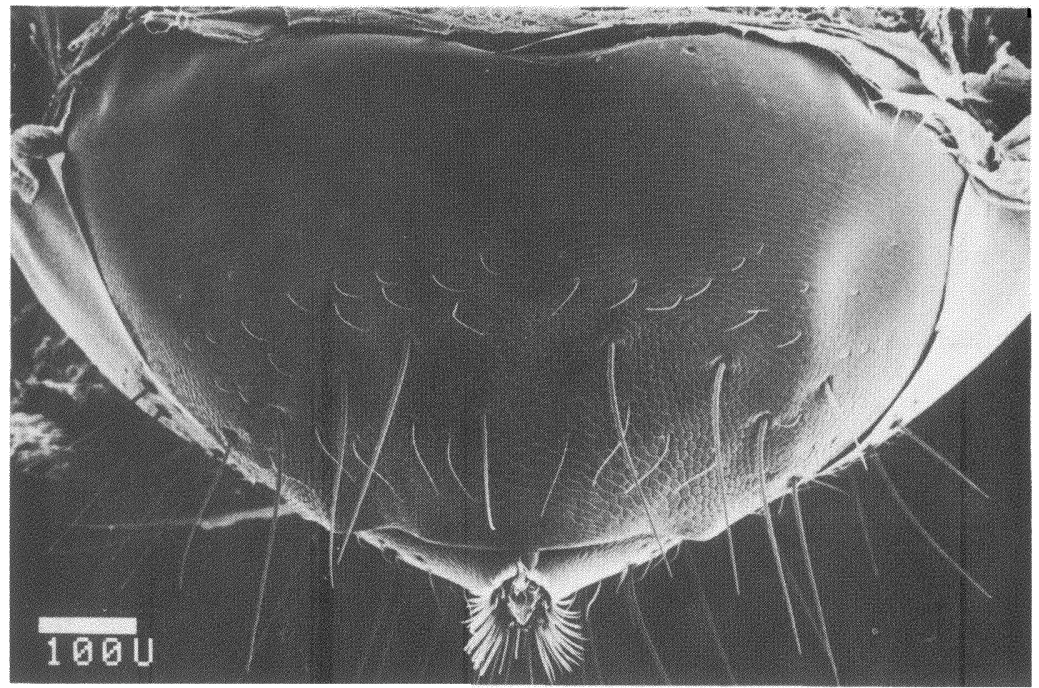

Fig. 6. SEM-photograph of the pygidium of a worker belonging to the Formica sanguinea group. Note: no cup structure on the anterior margin of the 7 th abdominal tergite.

around the leader ant, often moving briefly ahead, but always returning to the leader. Myrmecologists have long noted this peculiar looping behavior at the front of the raiding columns of Polyergus (see for example Schmitz 1906), but only the recent studies by Topoff have indicated that this appears to be due to the orgainizing role and excitement emanating from the leader ant. These observations suggest that the leader discharges not only a longer lasting trail pheromone but also an arousal signal, possibly from the pygidial gland.

Similar recruitment patterns have been observed in Camponotus socius and Myrmecocystus mimicus, where secretions from the poison gland seem to function as arousal signals (Hölldobler 1971, 1981), as well as in Camponotus ephippium, where the arousal signal appears to originate from the cloacal gland (Hölldobler 1982).

However, this hypothesis cannot be applied to the well developed pygidial gland in Polyergus queens. Wasmann (1915) first proposed that a young Polyergus queen, in order to found a new colony, has to intrude a colony of a slave ant species, where she kills the resident 
queen and is subsequently adopted as the "replacement" queen by the slave ant workers. This mode of parasitic colony founding was later confirmed in field observations by Gösswald (1932).

It is possible that the Polyergus queen achieves her acceptance in the foreign colony by emitting either a supernormal attractant or a disorganizing alarm substance (hence, some form of queen "propaganda" substance), possibly discharged from the pygidial gland. In fact, the pygidial gland secretions of Polyergus workers might also function as a kind of propaganda allomone when encountered by slave ants, very similar to the Dufour's gland secretions of the slave raiding species Formica pergandei and Formica subintegra which have a confusing propaganda effect on the raided slave ant colony (Regnier and Wilson 1971).

Further experimental work is required to determine which, if any, of these proposed speculations on the function of the Polyergus pygidial gland is correct.

\section{ACKNOWLEDGEMENTS}

I thank Hiltrud Engel-Siegel and Ed Seling for technical assistance, and Howard Topoff and Linda Goodloe who generously provided specimens of Polyergus breviceps and P. lucidus. This work was supported by NSF grant NBS 8219060.

\section{REFERENCES}

Gosswald, K.

1932. Okologische Studien über die Ameisenfauna des mittleren Maingebietes. Zeitschrift $\mathrm{f}$. Wissensch. Zoologie 142: 1-156.

HÖLLDOBLER, B.

1971. Recruitment behavior in Camponotus socius (Formicidae). Z. vergl. Physiol. 75: 123-142.

HOLLDOBLER, B.

1978. Ethological aspects of chemical communication in ants. Advances in the Study of Behavior. 8: 75-115.

HOLLDOBLER, B.

1981. Foraging and spatiotemporal territories in the honey ant Myrmecocystus mimicus Wheeler (Hymenoptera: Formicidae). Behav. Ecol. Sociobiol. 9: 301-314.

HOLLDOBLER, B.

1982a. Chemical communication in ants: new exocrine glands and their behavioral function. In: The Biology of Social Insects (ed. M. Breed, C. D. Michener, H. E. Evans). Westview Press, Boulder, Colorado. 
HOLLLOBLER, B.

1982b. The cloacal gland, a new pheromone gland in ants. Naturwissenschaften 69: 186.

HOLLDOBLER, B. AND H. ENGEL

1978. Tergal and sternal glands in ants. Psyche (Cambridge) 85: 285-330.

HólLDOBLER, B. AND H. ENGEL-SIEGEL

1982. Tergal and sternal glands in male ants. Psyche (Cambridge) 89: 113-132. Janet, CH.

1898. Etudes sur les Fourmis, les Guèpes et les Abeilles, Note 17: Systeme glandulaire tégumentaire de la Myrmica rubra. Observations diverses

JANET, CH. sur les Fourmis. Paris. Georges Carré et C. Naud, Éditeurs pp. 1-30.

1902. Anatomie du gaster de la Myrmica rubra. Paris, Georges Carré et C. Naud, Éditeurs pp. 1-63.

JEsSEN, K. AND U. Maschiwitz

1983. Abdominaldrüsen bei Pachy'condyla tridentata (Smith) (Formicidae, Ponerinae). Insectes Sociaux 30: 123-133.

Kugler, Ch.

1978. Pygidial glands in myrmicine ants (Hymenoptera, Formicidae). Insectes Sociaux 25: 267-274.

RATHMAYER, W.

1962. Methylmetacrylat als Einbettungsmedium für Insekten. Experientia (Basel) 18: 47-48.

REgNier, F. E. AND E. O. WILSON

1971. Chemical communication and "propaganda" in slave maker ants. Science 172: 267-269.

RoMeIS, B.

1948. Mikroskopische Technik. München 1948.

Schmitz, H.

1906. Das Leben der Ameisen und ihrer Gäste. Verlagsanstalt vorm. G. J. Manz., Buch-u. Kunstdruckerei, München-Regensburg.

TALBOT, M.

1967. Slave raids of the ant Polyergus lucidus Mayr. Psyche (Cambridge) 74: 299-313.

Topoff, H., B. LaMon, L. GoOdloe, and M. Goldstein

1984. Social and orientation behavior of Polyergus breviceps during slavemaking raids. Behav. Ecol. Sociobiol. 15: 273-279.

WASMANN, E.

1915. Gessellschaftsleben der Ameisen, Münster, 1915. 

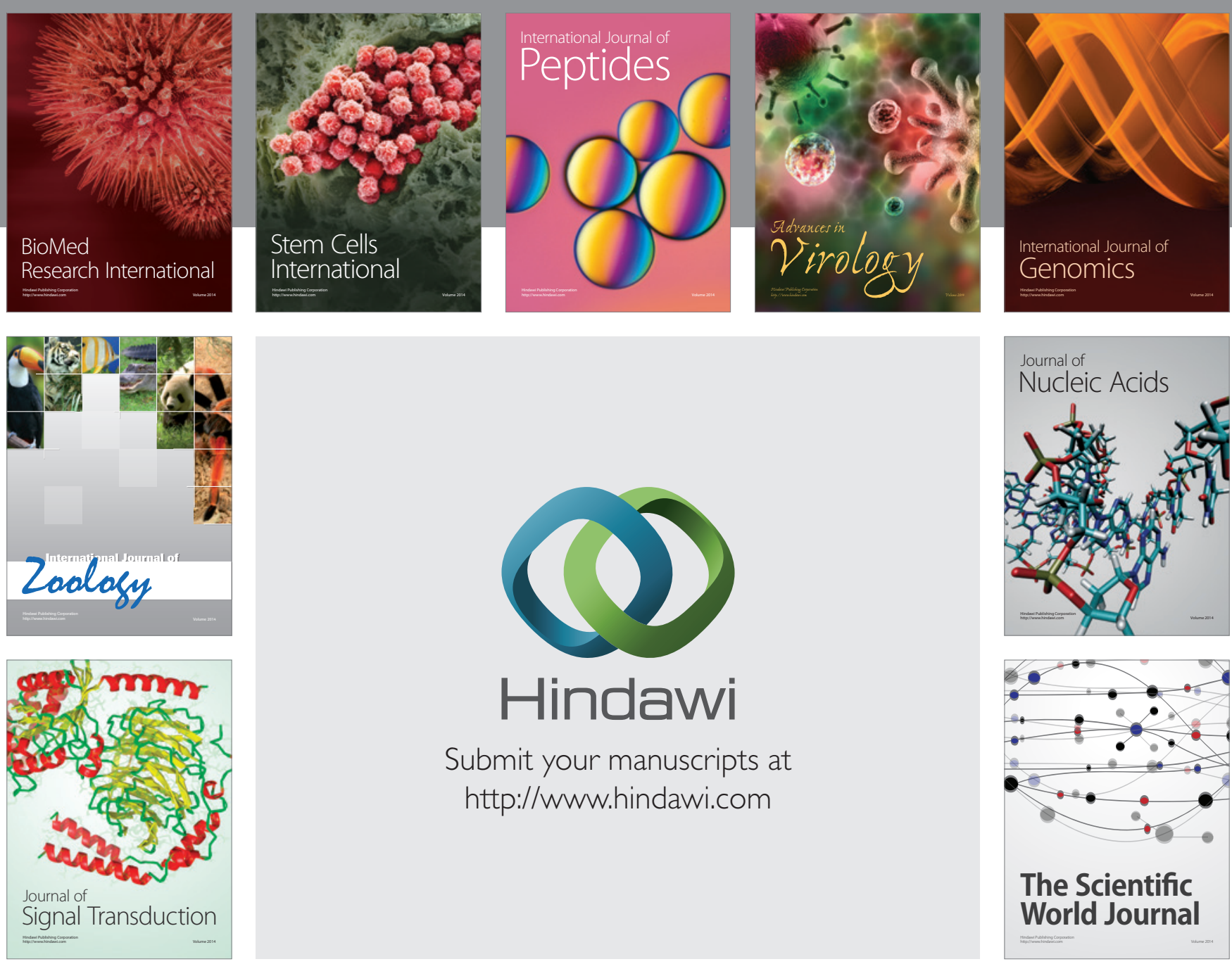

Submit your manuscripts at

http://www.hindawi.com
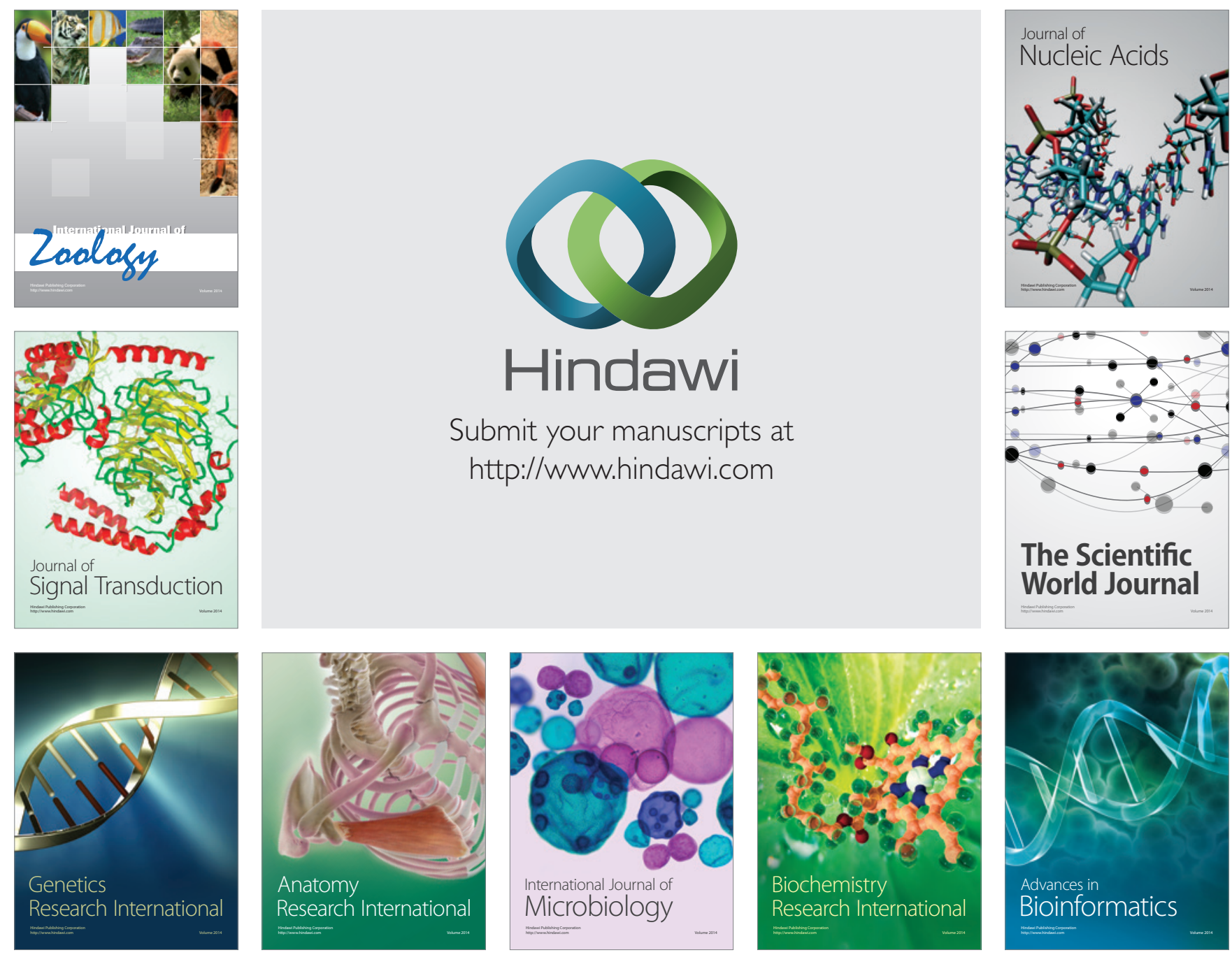

The Scientific World Journal
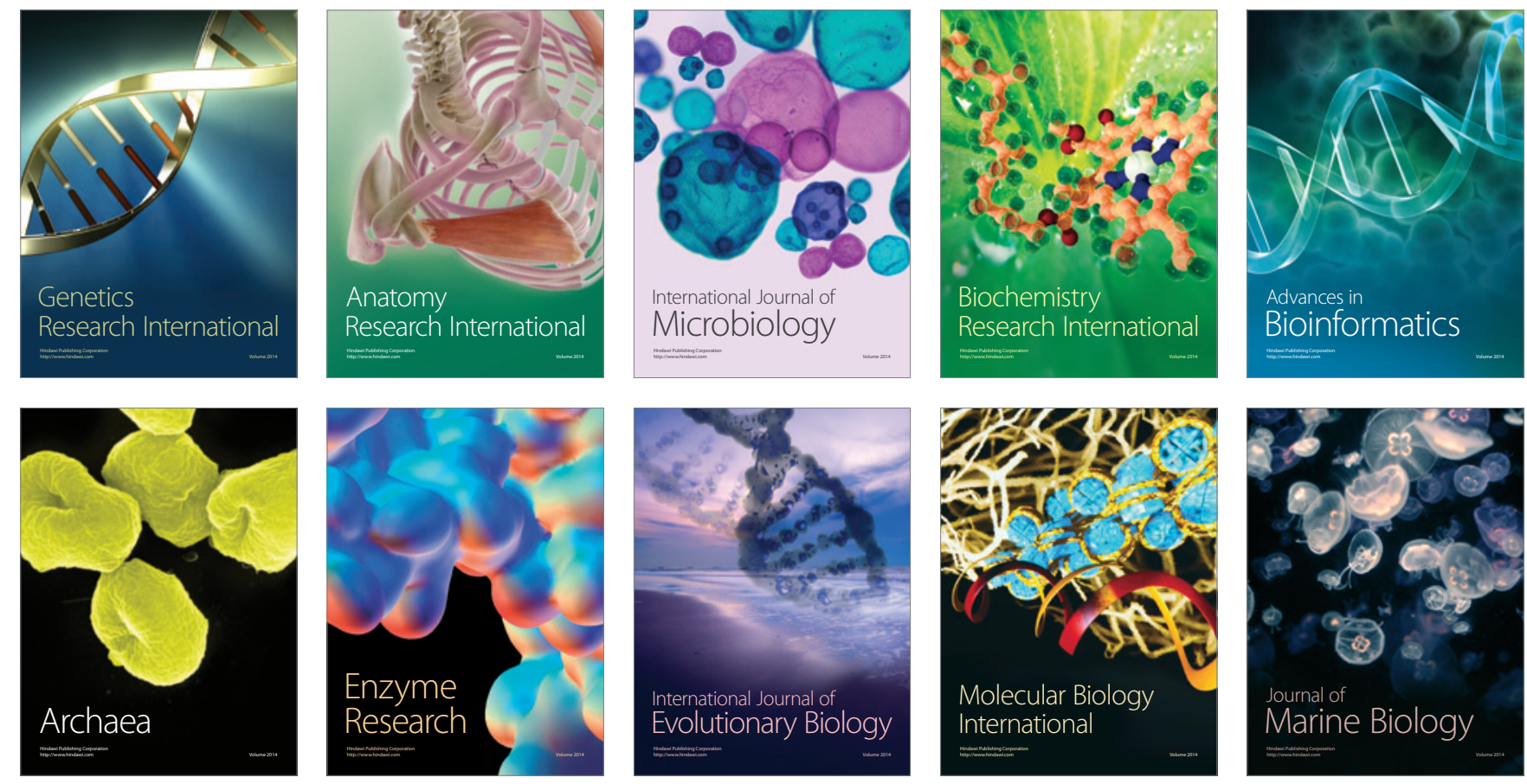